\title{
Incremental diagnostic utility of delayed enhancement CMR tissue characterization for detection of catheter associated right atrial thrombus
}

\author{
Andrew Plodkowski ${ }^{1}$, Nina Kukar ${ }^{1 *}$, Dipti Gupta ${ }^{1}$, Yulia Lakhman ${ }^{1}$, Jiwon Kim¹, Jennifer Liu', Nancy Roistacher ${ }^{1}$, \\ Stephen Solomon ${ }^{1}$, Richard Steingart ${ }^{1}$, Jonathan W Weinsaft ${ }^{1,2}$
}

From 18th Annual SCMR Scientific Sessions

Nice, France. 4-7 February 2015

\section{Background}

Right atrial thrombus (RT) provides a rationale for anticoagulation and substrate for embolic events. CMR is well validated for thrombus detection, but has yet to be used to assess prevalence and predictors of RA thrombus among at risk cohorts.

\section{Methods}

The population comprised consecutive patients with central venous catheters undergoing CMR at Memorial Sloan Kettering Cancer Center (NY, NY). Delayed enhancement CMR (inversion recovery GRE) was used to identify RT; defined as a right atrial (RA) mass with avascular tissue characteristics (non-enhancing) on "long TI" (600msec) DE-CMR. Cine-CMR (SSFP) was used to quantify cardiac structure and function, including RA and RV function and chamber size. Clinical indices were categorized based on medical record review. Echo (if performed within 14 days of CMR) was retrieved from image archives and independently read for RT. Clinical records were queried for documented pulmonary embolus (PE) within 60 days of CMR.

\section{Results}

50 cancer patients ( $50 \pm 17$ yo, $64 \%$ female) with RA catheters were studied. CMR was performed for evaluation of a suspected RA mass (36\%) or unrelated clinical indications (64\%). RT was present in $22 \%(\mathrm{n}=11)$; all had RT avascularity confirmed by dedicated "long TI" DE-CMR. Among affected patients, $63 \%$ had a solitary RT ( $36 \%$ multiple).
Patients with RT had similar right-sided structure and function vs. those without RT based on RA end-diastolic area $\left(10.2 \pm 3.5\right.$ vs. $\left.10.2 \pm 2.1 \mathrm{~cm}^{2} / \mathrm{m}^{2}, \mathrm{p}=0.94\right)$, RA end-systolic area $\left(6.9 \pm 3.7\right.$ vs. $\left.6.6 \pm 1.9 \mathrm{~cm}^{2} / \mathrm{m}^{2}, \mathrm{p}=0.76\right)$, RV enddiastolic volume ( $73 \pm 21$ vs. $67 \pm 16 \mathrm{ml} / \mathrm{m}^{2}, \mathrm{p}=0.27$ ), and RVEF ( $57 \pm 8$ vs. $59 \pm 9 \%, p=0.40)$. Cancer diagnosis (73 vs. $85 \%$ solid tumor, $\mathrm{p}=0.39)$, catheter depth $(2.3 \pm 2.2$ vs. 2.1 $\pm 1.8 \mathrm{~cm}$ from RA/SVC junction, $\mathrm{p}=0.74$ ), age and gender (both $\mathrm{p}=\mathrm{NS}$ ) were similar between groups. Transthoracic echo, attained $4.1 \pm 3.8$ days from CMR in $50 \%$ of the population, demonstrated high sensitivity (89\%) but moderate specificity (75\%) in relation to DE-CMR. Cine-CMR yielded similar sensitivity (82\%) but improved specificity (97\%) vs. the reference standard of DE-CMR (Table). 27\% of patients (3/11) with RT on DE-CMR had PE; all occurred prior to DE-CMR (average of 14 days before). Conversely, no PEs occurred among patients without RT. Clinical embolic events were independent of RT size (3.0 $\pm 2.6 \mathrm{~cm}^{2}$ vs. $\left.2.6 \pm 1.3 \mathrm{~cm}^{2}, \mathrm{p}=0.75\right)$.

\section{Conclusions}

Catheter associated RT occurs independently of rightsided structure or function, and is associated with clinical embolic events. Morphologic imaging by cine-CMR and echo provide limited diagnostic utility for RT as established by DE-CMR tissue characterization.

\section{Funding}

None. 
Table 1 Diagnostic performance of anatomic imaging for right atrial thrombus by DE-CMR tissue characterization.

\begin{tabular}{cccccc}
\hline & Sensitivity & Specificity & Accuracy & PPV & NPV \\
\hline Cine-CMR & $82 \%(9 / 11)$ & $97 \%(38 / 39)$ & $94 \%(47 / 50)$ & $90 \%(9 / 10)$ & $95 \%(38 / 40)$ \\
\hline Transthoracic Echo* & $89 \%(8 / 9)$ & $75 \%(12 / 16)$ & $80 \%(20 / 25)$ & $67 \%(8 / 12)$ & $92 \%(12 / 13)$ \\
\hline
\end{tabular}

*obtained in $50 \%$ of study population $(n=25)$

\section{Authors' details}

${ }^{1}$ Memorial Sloan Kettering Cancer Center, New York, NY, USA. ${ }^{2}$ Weill Cornell

Medical College, New York, NY, USA.

Published: 3 February 2015

doi:10.1186/1532-429X-17-S1-P327

Cite this article as: Plodkowski et al:: Incremental diagnostic utility of delayed enhancement CMR tissue characterization for detection of catheter associated right atrial thrombus. Journal of Cardiovascular

Magnetic Resonance 2015 17(Suppl 1):P327.

Submit your next manuscript to BioMed Central and take full advantage of:

- Convenient online submission

- Thorough peer review

- No space constraints or color figure charges

- Immediate publication on acceptance

- Inclusion in PubMed, CAS, Scopus and Google Scholar

- Research which is freely available for redistribution

Submit your manuscript at www.biomedcentral.com/submit 